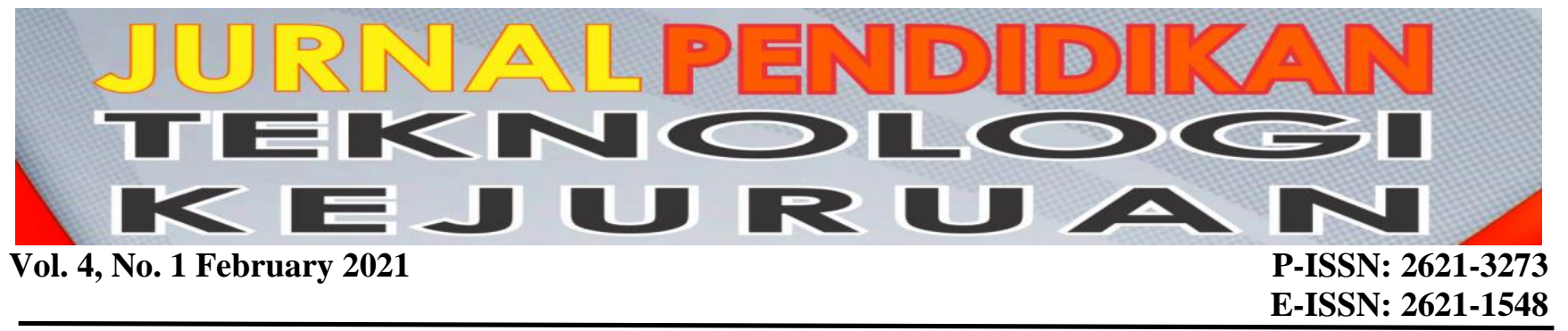

\title{
Contribution of Career Counseling, Internship Experience and Advisor Toward Students Work Readiness at Vocational High School
}

\author{
Kurniati Rahmadani, ${ }^{1}$ Dedy Irfan $^{2}$ \\ ${ }^{1}$ Electrical Engineering, Faculty of Engineering, Universitas Negeri Padang \\ ${ }^{2}$ Master Program of Mechanical Engineering, Faculty of Engineering, Universitas Negeri Padang \\ "Corresponding author, e-mail: kurniati_rahmadani@yahoo.com ${ }^{1}$
}

\begin{abstract}
The problems in this study are 1) The lack of subject relevance at schools with its implementation in the industrial world, 2) DU / DI instructors only guide what needs to be done in the field, without giving direct guidance, 3) Inadequate career guidance received by students at school. Students only get a little information related to the expertise program they choose, 4) The advisor is only limited to monitor students in the Internship, without providing optimal reinforcement and direction to students. This study aims to: 1) Contributing as career guidance to student work-readiness at SMKN 2 Padang, 2) Knowing the contribution of internship experience with student workreadiness at SMKN 2 Padang, 3) Knowing the contribution of the mentoring teacher to student work-readiness at SMKN 2 Padang, 4) Knowing contribution of internship career guidance and advisors together with the student workreadiness at SMKN 2 Padang. This type of research is quantitative using correlational research methods. This research was conducted at SMK Negeri 2 Padang. The population of this study was students of grade 12 at SMKN 2 Padang. The sampling technique was proportional random sampling, with a total sample of 83 students. The data analysis technique used is quantitative data analysis techniques. Based on the research results, it was found that the data were normal, linear, and did not occur multicollinearity. The results of the research are: 1) There is a contribution of career guidance to student work-readiness at SMKN 2 Padang, 2) There is a contribution of internship experience to student work-readiness at SMKN 2 Padang, 3) There is a contribution of an advisor to student workreadiness at SMKN 2 Padang, 4) Career Guidance Internship Experiences and advisors together provide a positive relationship to student work-readiness at SMKN 2 Padang by 78.0\%.
\end{abstract}

Keywords: career guidance, internship experience, advisors, job readiness

\section{INTRODUCTION}

SMK is a form and implementation of formal education that provides skills that are not provided by schools at the same level so that students can produce graduates who are able to work professionally and who have moral intelligence and skills. The purpose of establishing a vocational school is to create students to become workers who have skills and are ready to compete in the world of work. Therefore students need to have attitudes and skills in their fields in a professional manner.

From the data released by BPS in February 2019, the unemployment rate for SMK graduates is still among other education levels, which is $8.63 \%$. This indicates that not all SMK graduates can be absorbed by the industrial world. Therefore, it requires the readiness of students to be better prepared to face the world industry.
Student work readiness is the ability to adapt to their surroundings. Work readiness can also be interpreted as someone who is capable of doing a job well whether it is inside or outside the scope of work in order to create a good or service. Furthermore, work readiness can also be interpreted as behavior to identify, select, plan and implement goals according to the age of development (Abin, 2003).

One of PGD forms is practice in the form of internship. The purpose of conducting internship is that students are expected to gain experience and have a working picture in the industry. Internship is a program that must be implemented by students as a form of implementation of the knowledge they have acquired in school. Through Internship, students can absorb knowledge directly from industry and can apply it in the real world. After implementing Internship, 
students are expected to have complete and professional work readiness in their fields.

However, in its implementation in the field, there are still many problems related to industrial internship itself. Starting from inadequate school preparation to implement internship, internship places that do not give full confidence to students to go directly into the field, lack of guidance from internship instructors in industry and guidance from internship advisors who come from schools. As well as various other problems causing students to not optimally acquire skills or absorb knowledge when internship takes place.

Based on research conducted by Imam who studied the work readiness of vocational learners to work in the industry. The results showed that work readiness in understanding aspects including the very high category. Aspects of knowledge most learners have a very high work readiness category. Aspects of skill more than half of students have a work readiness in the high category. Aspects of personality most learners have a very high work readiness category. Overall indicates that most learners have a very high work readiness. It was concluded that the majority of vocational students are ready to work in the automotive body repair industry.

Through some relevant studies that have been studied, we can conclude that the work readiness of vocational students is relative. Depending on the internal and external aspects that influence it. If these aspects has been implemented optimally, then the work readiness of students also up, nor vice versa. Based on the observations that the researcher carried out at SMKN 2 Padang as the research object, the researcher obtained some information related to industrial internship. Through interviews with students who have conducted Internship, researchers get information that the material they learned at school is less relevant to its implementation in the industrial world. In addition, the DU / DI instructors only provide direction on what needs to be done in the field, without direct guidance.

The next problem encountered in the field is the inadequate career guidance students receive at school. Students get very little information regarding the program of expertise they choose. So that students cannot fully understand the expertise program they are engaged in.

In addition, when the internship program is ongoing, the advisor just monitored students in the internship program. The advisor checks attendance and asks about the development of students in the industrial world to the DU/DI instructor. The advisor should have asked students to what extent the relevance of science in schools with the industrial world, and provided optimal reinforcement and direction to students. So that the knowledge and skills obtained by students in the field are maximized. This can lead to an increase in the work readiness of students.

Based on several problems and to see the truth of the facts on, therefore, the researcher raised the research title "The Contribution of Career Counseling, Internship Experience and Advisor toward The Student Work Readiness SMKN 2 Padang." Then able to prove phenomena in the field, as well as provide constructive suggestions for schools and industry.

\section{METHOD}

This study uses correlational quantitative research methods. Quantitative research methods are methods used to examine a specific population or sample, data collection using research instruments, statistical data analysis, with the aim of testing the proposed hypothesis (Sugiyono, 2013). Meanwhile, correlational research is a study to determine the relationship and level of the relationship between two or more variables without any attempt to influence these variables so that there is no manipulation of the variables (Creswell, 2008).

The research was conducted at SMKN 2 Padang with the research subjects of XII grade students. The research time was in the even semester of the 2020/2021 school year. The population is 492 students, and the sample is 83 students based on proportional random sampling.

\section{RESULT AND DISCUSSION}

In the description section of this data, it is described in detail about the contribution of career counseling, internship experience and advisor toward the student work readiness at SMK Negeri 2 Padang. In this study, students were the object of research, after taking the sample, 83 respondents were obtained.

All research data that enter and meet the requirements, are processed and analyzed to reveal information in accordance with the objectives of this study. In short it can be stated that the description of the research data is like the following table: 
Table. 1 responden data

\begin{tabular}{|l|r|r|r|r|}
\hline & \multicolumn{1}{|c|}{ X1 } & \multicolumn{1}{c|}{ X2 } & \multicolumn{1}{c|}{ X3 } & \multicolumn{1}{c|}{$\mathrm{Y}$} \\
\hline $\mathrm{N} \quad$ Valid & 83 & 83 & 83 & 83 \\
Mean Missing & 0 & 0 & 0 & 0 \\
Std. Error of & 99,94 & 86,14 & 63,29 & 97,72 \\
Mean &, 813 &, 794 &, 492 &, 752 \\
Median & 99,00 & 85,00 & 64,00 & 96,00 \\
Mode & 97 & 80 & 61 & 95 \\
Std. Deviation & 7,407 & 7,232 & 4,479 & 6,849 \\
Variance & 54,862 & 52,296 & 20,062 & 46,910 \\
Range & 28 & 30 & 18 & 28 \\
Minimum & 84 & 70 & 54 & 84 \\
Maximum & 112 & 100 & 72 & 112 \\
Sum & 8295 & 7150 & 5253 & 8111 \\
\hline
\end{tabular}

Source: Independent Data Processing (2021)

Based on the statistical analysis for the X1 variable, it was obtained that the number of data $(\mathrm{N})$ was filled in as many as 83 respondents, the average (mean) for each answer score was 99.94, with the smallest answer (min) answered by the respondent obtained 84, the result of the answer Most $(\max )$ answered by the respondent was obtained 112, while the standard deviation of each respondent's score was 7.407. Furthermore, the median for the motivation variable is 99, with a mode of 97.

Based on the statistical analysis for the X2 variable, it was obtained that the number of data $(\mathrm{N})$ was filled in as many as 83 respondents, the average (mean) for each answer score was 86.14, with the smallest answer (min) answered by the respondent was obtained 70, the result of the answer Most (max) answered by the respondents obtained 100, while the standard deviation of each respondent's answer score was 7,232. Furthermore, the median for the motivation variable is 85 , with a mode of 80 .

Based on the statistical analysis for the $\mathrm{X} 3$ variable, it was obtained that the number of data $(\mathrm{N})$ was filled in as many as 83 respondents, the average (mean) of each answer score was 63.29, with the smallest answer (min) answered by the respondent was obtained 54, the result of the answer The most $(\max )$ answered by the respondents was 72 , while the standard deviation of each respondent's score was 4.479. Furthermore, the median for the motivation variable is 64 , with a mode of 61 .

Based on the statistical analysis for variable $\mathrm{Y}$, it was obtained that the number of data $(\mathrm{N})$ filled in was 83 respondents, the average (mean) on each answer score was 97.72, with the smallest answer ( $\mathrm{min}$ ) answered by the respondent was obtained 84 , the result of the answer The most (max) answered by the respondents was 112, while the standard deviation of each respondent's score was 6,849. Furthermore, the median for work readiness variable is 96 , with a mode of 95.

Hypothesis testing is carried out by $t$ test partially and simultaneously. The analysis requirements that need to be met are normality, linearity and multicollinearity tests, namely:

Table 2 Normality Test

\begin{tabular}{|ll|r|r|r|r|}
\hline & & \multicolumn{1}{c|}{ X1 } & \multicolumn{1}{c|}{ X2 } & \multicolumn{1}{c|}{ X3 } & \multicolumn{1}{c|}{ Y } \\
\hline N & & 83 & 83 & 83 & 83 \\
Normal & Mean & 99,83 & 86,14 & 63,29 & 97,72 \\
Parameters2, & Std. & 7,516 & 7,232 & 4,479 & 6,849 \\
& Deviation & & & &, 117 \\
Most & Absolute &, 076 &, 141 &, 132 \\
Extreme & Positive &, 056 &, 117 &, 141 &, 132 \\
Differences & Negative &,- 076 &,- 090 &,- 081 &,- 095 \\
Kolmogorov-Smirnov Z &, 693 & 1,067 & 1,286 & 1,206 \\
Asymp. Sig. (2-tailed) &, 723 &, 205 &, 073 &, 109 \\
\hline
\end{tabular}

Source: Independent Data Processing (2021)

Table 2 shows the probability (sign) of the four variables $>\alpha=0.05$. The probability (sign) of the career guidance variable (X1) is 0.723 , the internship experience variable $(\mathrm{X} 2)$ is 0.205 , the advisory teacher variable $(\mathrm{X} 3)$ is 0.073 and the student work readiness variable $(\mathrm{Y})$ is 0.109 . It can be concluded that the four variable data contribute normally which means that the data is good in quality.

The results of the calculation of the linearity test of the career guidance variable (X1), internship experience (X2) and the advisor (X3) on the student work readiness $(\mathrm{Y})$ :

Table 3 linearity test $\mathrm{X}_{1}$ and $\mathrm{Y}$

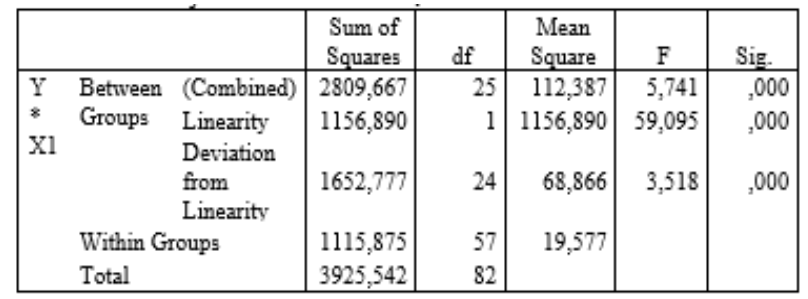

Source: Independent Data Processing (2021)

Based on table 3 above, a linearity probability (sign) of 0.000 is obtained smaller than 0.05 , it can be concluded that the data distribution of the independent variables forms a linear line to the dependent variable.

Obtained a probability of linearity (sign) of 0.000 smaller than 0.05 , it can be concluded that the data distribution of the independent variables forms a linear line to the dependent variable. 
Table 4 linearity test $\mathrm{X}_{3}$ and $\mathrm{Y}$

\begin{tabular}{|c|c|c|c|c|c|c|c|}
\hline & & & $\begin{array}{l}\text { Sum of } \\
\text { Squares }\end{array}$ & Df & $\begin{array}{l}\text { Mean } \\
\text { Square }\end{array}$ & $\mathrm{F}$ & Sig. \\
\hline \multirow{6}{*}{$\begin{array}{l}\mathrm{Y} \\
8 \\
\mathrm{X} 3\end{array}$} & Between & (Combined) & 2646,020 & 17 & 155,648 & 7,907 & .000 \\
\hline & Groups & Linearity & 1589,774 & 1 & 1589,774 & 80,761 &, 000 \\
\hline & & Deviation & & & & & \\
\hline & & $\begin{array}{l}\text { from } \\
\text { Linearity }\end{array}$ & 1056,246 & 16 & 66,015 & 3,354 &, 000 \\
\hline & \multicolumn{2}{|c|}{ Within Groups } & 1279,522 & 65 & 19,685 & & \\
\hline & \multicolumn{2}{|c|}{ Total } & 3925,542 & 82 & & & \\
\hline
\end{tabular}

Source: Independent Data Processing (2021)

Obtained a probability of linearity (sign) of 0.000 smaller than 0.05 , it can be concluded that the data distribution of the independent variables forms a linear line to the dependent variable. Because the linearity test has been fulfilled, it can be continued with the multicollinearity test.

Table 5 Multikolinearitas test

\begin{tabular}{|c|c|c|c|c|c|}
\hline \multirow{2}{*}{ Model } & \multirow{2}{*}{$\mathrm{T}$} & \multirow{2}{*}{ Sig. } & \multicolumn{2}{|c|}{$\begin{array}{c}\text { Collinearity } \\
\text { Statistics }\end{array}$} & \multirow{2}{*}{ Keterangan } \\
\cline { 5 - 6 } & & & Tolerance & VIF & \\
\hline 1 (Constant) &, 013 &, 989 & & & \\
$\mathrm{X} 1$ & 4,271 &, 000 &, 747 & 1,339 & Independen \\
$\mathrm{X} 2$ & 4,095 &, 000 &, 771 & 1,297 & Independen \\
$\mathrm{X} 3$ & 10,500 &, 000 &, 828 & 1,208 & Independen \\
\hline
\end{tabular}

Source: Independent Data Processing (2021)

Thus it can be concluded that the three independent variables do not occur multicollinearity problems. Furthermore, the hypothesis testing is carried out. The first hypothesis in this study is that there is a relationship between Career Guidance and Student Work Readiness at SMKN 2 Padang. The hypothesis was tested using a simple regression technique with the stepwise method.

Table 6 Career Guidance and Student Work Readiness

\begin{tabular}{|l|c|c|c|c|}
\hline Model & $\mathrm{R}$ & $\begin{array}{c}\mathrm{R} \\
\text { Square }\end{array}$ & $\begin{array}{c}\text { Adjusted } \mathrm{R} \\
\text { Square }\end{array}$ & $\begin{array}{c}\text { Std. Error of the } \\
\text { Estimate }\end{array}$ \\
\hline 1 &, $565^{2}$ &, 320 &, 311 & 5,684 \\
\hline
\end{tabular}

Source: Independent Data Processing (2021)

Based on the simple correlation analysis in table 6, it can be seen that the correlation coefficient rcount for $\mathrm{N}=83$ and the error rate of $5 \%$ is $\mathrm{r}_{\text {table }}=0.213$ (Appendix 9). With the provision that if $\left(\mathrm{r}_{\text {count }}<\mathrm{r}_{\text {table }}\right)$ there is no relationship between Career Guidance and Student Work Readiness at SMKN 2 Padang (H0). Furthermore, if $\left(r_{\text {count }}>r_{\text {table }}\right)$ there is a relationship between Career Guidance and Student Work Readiness at SMKN 2 Padang (Ha). Based on the results of the analysis carried out, the value of $r_{\text {count }}>r_{\text {table }}(0.565>0.213)$ was obtained.

This shows that career guidance has a positive relationship with job readiness, amounting to 0.565 .
So it can be concluded that career guidance with student work readiness has a significant correlation at the 5\% error level. Furthermore, in table 4.11, the price $r_{\text {count }}=0.565$ and $r_{\text {table }}=0.213$. So that it can be said $r_{\text {count }}(0.565)>r_{\text {table }}(0.213)$ or significant <alpha $(0.000$ $<0.005)$, then the $r_{\text {square }}$ is obtained of 0.320 . This shows that the relationship between Career Guidance and Student Work Readiness is 0.320 or $32.0 \%$, meaning that the better the career guidance, the better the student's work readiness. This shows that motivation is positively related to student work readiness by $32.0 \%$.

The second hypothesis in this study is that there is a relationship between the experience of industrial internships and the student work readiness at SMKN 2 Padang. The hypothesis was tested using a simple regression technique with the stepwise method. Based on the results of a simple correlation analysis, the experience of industrial internship on the Readiness of Students at SMKN 2 Padang is in the following table 7.

Table 7 Industrial Internship and Student Work Readiness

\begin{tabular}{|l|c|c|c|c|}
\hline Model & $\mathbf{R}$ & R Square & $\begin{array}{c}\text { Adjusted R } \\
\text { Square }\end{array}$ & $\begin{array}{c}\text { Std. Error of the } \\
\text { Estimate }\end{array}$ \\
\hline 1 &, $790^{2}$ &, 624 &, 619 & 4,228 \\
\hline
\end{tabular}

Source: Independent Data Processing (2021)

Based on the simple correlation analysis in table 4.13, it can be seen that the correlation coefficient $r_{\text {count }}$ for $\mathrm{N}=83$ and the error rate of $5 \%$ is $\mathrm{r}$ table $=0.213$ (Appendix 9). With the provision that if $\left(r_{\text {count }}>r_{\text {table }}\right)$ there is no relationship between internship experience and the Readiness of Students at SMKN 2 Padang (H0). Furthermore, if $\left(r_{\text {count }}>r_{\text {table }}\right)$ there is a relationship between internship experience and the Readiness of Students at SMKN 2 Padang (Ha). Based on the results of the analysis carried out, the value of $r_{\text {count }}>r_{\text {table }}(0.790>0.213)$ was obtained.

This shows that the internship experience has a positive relationship with Work readiness, which is equal to 0.790 . So it can be concluded that Career Guidance with student work readiness has a significant correlation at the $5 \%$ error level.

Furthermore, in table 7, the price $r_{\text {count }}=0.790$ and $r_{\text {table }}$ $=0.213$. So it can be said that $r_{\text {count }}(0.781)>r_{\text {table }}$ $(0.790)$ or significant <alpha $(0.000<0.005)$, then the $\mathrm{r}_{\mathrm{square}}$ is 0.624 . This shows that the relationship between internship experience and the student work readiness is 0.624 or $62.4 \%$, meaning that the better the internship experience, the better the student work readiness. This shows that the internship experience 
has a positive relationship with student work readiness by $62.4 \%$.

Table 8 Internship Experience and Student Work Readiness Source: Independent Data Processing (2021)

\begin{tabular}{|l|l|r|r|r|}
\hline Model & R & R Square & $\begin{array}{c}\text { Adjusted R } \\
\text { Square }\end{array}$ & $\begin{array}{c}\text { Std. Error of } \\
\text { the Estimate }\end{array}$ \\
\hline 1 &, $598^{2}$ &, 357 &, 349 & 5,525 \\
\hline
\end{tabular}

The third hypothesis in this study is that there is a contribution from the Guidance Teacher to the Student Work Readiness at SMKN 2 Padang. The hypothesis was tested using a simple regression technique with the stepwise method.

Based on the simple correlation analysis in table 8 , it can be seen that the correlation coefficient $\mathrm{r}_{\text {count }}$ for $\mathrm{N}$ $=83$ and the error rate of $5 \%$ is $\mathrm{r}$ table $=0.213$ (Appendix 9). With the provision that if $\left(\mathrm{r}_{\text {count }}<\mathrm{r}_{\text {table }}\right)$ there is no relationship between internship experience and the Readiness of Students at SMKN 2 Padang (H0). Furthermore, if $\left(r_{\text {count }}>r_{\text {table }}\right)$ there is a relationship between internship experience and the Student Work Readiness at SMKN 2 Padang (Ha). Based on the results of the analysis carried out, the value of $r_{\text {count }}>r_{\text {table }}(0.598>0.213)$ was obtained.

This shows that the internship experience has a positive relationship with work readiness, which is 0.598. So it can be concluded that Career Guidance with Students Work Readiness has a significant correlation at the $5 \%$ error level.

The fourth hypothesis in this study is that there is a joint contribution of Internship Experience Career Guidance and Guidance Teachers to the Student Work Readiness at SMKN 2 Padang. This hypothesis was tested using multiple correlation techniques.

Based on the simple correlation analysis in table 9 , it can be seen that the correlation coefficient $r$ calculated for $\mathrm{N}=83$ and the $5 \%$ error rate is $\mathrm{r}$ table $=0.213$ (Appendix 9). With the provision if $\left(\mathrm{r}_{\text {count }}<\mathrm{r}_{\text {table }}\right)$ there is no relationship between Career Development Practical Work Experience and Guidance Teachers along with student work readiness $(\mathrm{H} 0)$. Furthermore, if $\left(\mathrm{r}_{\text {count }}>\mathrm{r}_{\text {table }}\right)$ then there is a relationship between the Internship Experience Career Development and the Guidance Teacher together on student work readiness $(\mathrm{Ha})$. Based on the results of the analysis carried out, the value of $r_{\text {count }}>r_{\text {table }}(0.883>$ 0.213) was obtained.
Table 9 Double Correlation $\mathrm{X}_{1} \mathrm{X}_{2} \mathrm{X}_{3}$ to $\mathrm{Y}$

\begin{tabular}{|l|c|r|r|c|}
\hline Model & $\mathbf{R}$ & $\begin{array}{c}\mathrm{R} \\
\text { Square }\end{array}$ & $\begin{array}{c}\text { Adjusted } \\
\text { R Square }\end{array}$ & $\begin{array}{c}\text { Std. Error of } \\
\text { the Estimate }\end{array}$ \\
\hline 1 &, $883^{2}$ &, 780 &, 772 & 3,306 \\
\hline
\end{tabular}

Source: Independent Data Processing (2021)

Internship experience has a positive relationship with work readiness, which is equal to 0.883 . So it can be concluded that Career Guidance with student work readiness has a significant correlation at the $5 \%$ error level. Furthermore, in table 4.17, the price $r_{\text {count }}=0.883$ and $r_{\text {table }}=0.213$. So it can be said $r$ count $(0.883)>r$ table $(0.213)$ or significant <alpha $(0.000<0.005)$, then the $r_{\text {square }}$ is 0.780 . This shows that the relationship between the internship experience and the Students Work Readiness is 0.780 or $78.0 \%$, meaning that the better the internship experience, the better the students work readiness. This shows that the internship experience has a positive relationship with students work readiness by $78.0 \%$.

Many things can affect the readiness for work of students, both factors from outside and from themselves. Currently the unemployment rate for junior high school students is higher than other levels of education, whereas, as we know, junior high school students are required to be able to work after completing their education. Because this requires a breakthrough so that our graduates can prepare themselves before graduating from school, so that they are able to find jobs that suit themselves..

Work readiness is the ability to adapt and complete a given job, adapt to the work environment, both colleagues and the work being done. To support the work readiness of students, schools have provided facilities such as consultations with teachers and or internship practices. With the existence of career guidance, internship, and the role of the guidance teacher, it is able to provide a picture of life in the world of work, so that students do not feel awkward when they are in the professional world..

\section{CONCLUSION}

From the analysis that has been carried out, the contribution of career guidance and internship experience and guidance teachers to the student work readiness at SMK N 2 Padang, it can be concluded that:

1. There is a contribution of career guidance to student work readiness at SMK N 2 Padang. It was found that $t_{\text {count }}=7,455$ with a significance value obtained of 0,000 . If the value of $t_{\text {count }}>t_{\text {table }}$, then there is a significant relationship, if $\mathrm{t}_{\text {count }}<\mathrm{t}_{\text {table }}$ then there is no significant relationship. The ttable value at $5 \%$ alpha is $\mathrm{dk}=\mathrm{N}-3-1$ or $\mathrm{dk}=83-4=79$, the $\mathrm{t}$ 
table value is 1.990 . When compared to tcount 6.168 with ttable 1.990 , it can be seen that $t_{\text {count }}>t_{\text {table. }}$. Therefore, it can be concluded that there is a relationship between career guidance and student work readiness at SMK N 2 Padang.

2. There is a contribution from the internship experience to the student work readiness at SMKN 2 Padang. Then it can be $t$ count $=10,997$ with a significance value obtained of 0,000 . If the value of $t_{\text {count }}>t_{\text {table }}$, then there is a significant relationship, if $\mathrm{t}_{\text {count }}<\mathrm{t}_{\text {table }}$ then there is no significant relationship. The ttable value at $5 \%$ alpha is $\mathrm{dk}=\mathrm{N}-3-1$ or $\mathrm{dk}=$ $83-4=79$, the $\mathrm{t}$ table value is 1.990 . When compared to tcount 11.585 with $t_{\text {table }} 1.990$, it can be seen that $t_{\text {count }}>t_{\text {table. Therefore, it can be }}$ concluded that there is a relationship between internship experience and student work readiness at SMK N 2 Padang.

3. There is a contribution from the guidance teacher to the student work readiness at SMK N 2 Padang. Then it can be $t_{\text {count }}=6,720$ with a significance value obtained of 0,000 . If the value of $t_{\text {count }}>t_{\text {table }}$, then there is a significant relationship, if $\mathrm{t}_{\text {count }}<\mathrm{t}_{\text {table }}$ then there is no significant relationship. The ttable value at $5 \%$ alpha is $\mathrm{dk}=\mathrm{N}-3$ or $\mathrm{dk}=83-4=79$, the $\mathrm{t}$ table value is 1.990 . When compared to tcount 6,720 with ttable 1,990 , it can be seen that $\mathrm{t}_{\text {count }}<\mathrm{t}_{\text {table. }}$. Therefore, it can be concluded that there is a relationship between internship experience and student work readiness at SMK N 2 Padang.

4. It can be seen that the statistical significance value in the $\mathrm{F}$ test is 93.364 with a probability of 0.000 , because the probability value is smaller than alpha 0.05 or at the $95 \%$ confidence level. For the twoparty test, the $\mathrm{F}$ table (attachment 11) is 2.72 . Obtained the value of $\mathrm{F}_{\text {count }}>\mathrm{F}_{\text {table }}$, then $\mathrm{HO}$ is rejected, meaning that there is a contribution of Career Guidance, Internship Experience and Guidance Teachers together on the Student Work Readiness at SMKN 2 Padang. With the presence of a significant correlation, it can be concluded that the Internship Experience Career Guidance and the Guidance Teacher together provide a positive relationship to the students work readiness at SMK N 2 Padang by $78.0 \%$.

\section{REFERENCES}

Abin, Syamsuddin. 2003. The Nature of Supervisory Teachers. Jakarta: Tristo.

Agus, Irianto. 1988. Educational Statistics. Jakarta: Ministry of Education and Culture.
Ahmad, Timsal, et al. 2016. On job Training and Its Effectiveness: An Employee Perspective. South Asian Journal of Banking and Social Sciences, 2 (1).

Alex Sobur. 2003. General Psychology. Bandung: Faithful Library.

Anas, Sudijono. 2011. Introduction to Educational Evaluation. Jakarta: Rajawali Press.

Anne, O., et al. 2018. Career Guidance and Counseling in Uganda, Current Developments and Challenges. International Journal of Innovative Research and Development, 7 (11), 107-113.

Babatunde \& Ojo, J. 2017. Effects Of Career Guidance And Career Counseling Techniques On Students Vocational Maturity. European Journal of Education Studies, 3 (6), 717-727.

Caballero, C., et al. 2010. Work Readiness In Graduate Recruitment And Selection: A Review Of Current Assessment Methods. Journal of Teaching and Learning for Graduate Employability, 1 (1), 13-25.

Chaplin, J.P. 2006. Complete Dictionary of Psychology. Jakarta: PT. Raja Grafindo Persada.

Creswell. 2008. Types of Research. Bandung: Alfabeta.

Imam A. Alimudin, dkk. 2018. Kesiapan Kerja Siswa di Dunia Industri. Jurnal Pendidikan, 1(2), Hal. 154162.

Sugiyono. 2013. Metode Penelitian Kuantitatif Kualitatif dan R\&D. Bandung: Alfabeta. 